\title{
Evaluation of the Effect of Agricultural Management on Energy Yield and Greenhouse Gas Emission Reduction of Bioenergy Production Chains
}

\author{
Sjaak Conijn ${ }^{1}$, Wim Corré1, Hans Langeveld ${ }^{2}$, Jacques Davies ${ }^{1}$ \\ ${ }^{1}$ Plant Research International, Wageningen University and Research Centre (WUR), Wageningen, \\ The Netherlands \\ ${ }^{2}$ Biomass Research, Wageningen, The Netherlands \\ Email: ${ }^{*}$ sjaak.conijn@wur.nl
}

Received 16 February 2014; revised 27 March 2014; accepted 16 April 2014

Copyright @ 2014 by authors and Scientific Research Publishing Inc.

This work is licensed under the Creative Commons Attribution International License (CC BY). http://creativecommons.org/licenses/by/4.0/

(c) (i) Open Access

\section{Abstract}

The role of energy crops in reducing fossil energy use and greenhouse gas emission is much debated. To improve decision making on the use of crops for producing bioenergy, a tool (Energy Crop Simulation Model or E-CROP) has been developed to calculate 1) sustainable crop dry matter yield levels as function of agricultural inputs, and 2) gross and net energy yield and greenhouse gas emission reduction, covering the entire bioenergy production chain from sowing to distribution of bioenergy. E-CROP can be applied to a wide range of crops, soils, climatic conditions, management choices, and conversion technologies. This paper describes E-CROP and focuses on its application on four arable crops, as cultivated on two contrasting sites in the Netherlands (potato and sugar beet for bioethanol, winter oilseed rape for biodiesel and silage maize for bioelectricity) and on the effect of crop management (viz. irrigation and nitrogen fertilisation). In all situations, gross energy output exceeded total energy input. Calculated for an average situation, net energy yield ranged from 45 to $140 \mathrm{GJ} \cdot \mathrm{ha}^{-1}$. Lowering irrigation and/or fertilisation input levels generally resulted in a reduction of net energy yields. The net reduction of greenhouse gas emissions in the average situation ranged from 0.60 to $6.5 \mathrm{t} \mathrm{CO}_{2}$-eq $\cdot \mathrm{ha}^{-1}$. In general, $\mathrm{N}_{2} \mathrm{O}$ emission from nitrogen fertiliser caused large variations in the net reduction of greenhouse gas emission, which even became negative in some situations. Lowering nitrogen fertilisation to levels that are suboptimal for net energy yields enhanced the net reduction in greenhouse gas emission, implicating that both goals cannot be optimised simultaneously. Agricultural knowledge is important for optimising the outputs of bioenergy production chains.

\footnotetext{
*Corresponding author.
} 


\section{Keywords}

\section{Energy Crops, Biodiesel, Bioethanol, Bioelectricity, Sustainable Production, Energy Yield, Greenhouse Gas Emission}

\section{Introduction}

Human energy consumption largely depends on fossil sources; in the EU, e.g., nearly $80 \%$ of total energy consumption in 2003 was of fossil origin [1]. This situation is undesirable in view of the large $\mathrm{CO}_{2}$ emissions from burning fossil fuels causing global warming. Moreover, fossil energy is not renewable and will become exhausted in the future. Consequently, possibilities of replacing fossil energy by alternative energy sources are investigated and developed. This is not a new phenomenon; "alternative energy" was already prominent on policy and research agendas in the $20^{\text {th }}$ century [2] but the interest declined at the end of that century. Recent increases in oil prices, instability of major oil producing regions, and growing concern about extent and risks of global warming, however, have refuelled the attention for alternative energy sources. This interest is further intensified by national and international policies, such as the EU Biofuels Directive of 2003 and the EU Renewable Energy Directive of 2009 imposing future targets for the use of renewable energy in the EU and sustainability criteria for the production of renewable energy [3] [4].

Biomass is one of the sources that can replace fossil energy. This all-round substitute for fossil energy can be converted into transportation fuel (biofuel), bioelectricity and heat, all using easily available technologies. Examples are cars running on fuel mixtures with ethanol or biodiesel and farmer's installations generating electricity from biogas, produced by anaerobic digestion of manure and/or biomass. Biomass for energy production can be obtained from waste of food production and consumption as well as from landscape and nature management. However, a substantial increase of the contribution of bioenergy requires dedicated production of woods or crops. Crops can be especially interesting for energy production, as they are suitable for production of biofuels, e.g. bioethanol from sugar or starch and biodiesel from vegetable oil, but they can also serve other goals, such as the use of part of the crop as food or feed, while the remainder is used for energy production. This paper focuses on bioenergy production chains that are based on crop biomass.

Many countries stimulate the use of (arable) crops for energy production to reduce fossil energy consumption. However, a number of questions still require attention.

One key issue is how much fossil energy can be replaced by energy crops. Debate on this question is still continuing, mostly focusing on ethanol production from maize; see, e.g., the review by Hammerschlag [5] and the discussion in [6]. It is therefore necessary to determine net energy yields of bioenergy production chains, expressed in amount of replaced fossil energy, covering all inputs and outputs, and perform this analysis in a consistent way to compare various crops and technologies.

Another key issue is related to the net reduction of greenhouse gas (GHG) emissions. This reduction is not proportional to the net replacement of fossil energy mostly because $\mathrm{N}_{2} \mathrm{O}$ emissions occur during the production and application of nitrogen $(\mathrm{N})$ fertilisers used in crop production. This $\mathrm{N}_{2} \mathrm{O}$ effect may enhance instead of reduce GHG emissions, even in situations where net energy yields are positive. The main question here is how much emission of $\mathrm{CO}_{2}$ equivalents can be avoided by replacing fossil energy by bioenergy from energy crops. Evaluation of bioenergy production chains should therefore include a calculation of the net reduction of GHG emissions, as this is one of the main reasons for using non-fossil energy sources. Some authors have included this aspect in their analysis of bioenergy crop production [7] [8] whereas others do not [9] [10] and in the EU action was taken to introduce limits to the minimum GHG emission reduction to be reached by the use of biofuels produced from crops [4]. Much debated is the effect of (direct and indirect) Land Use Change (LUC) on the GHG emission reduction of replacing fossil fuels by fuels made from crops. LUC usually has a strong negative impact on the storage of carbon in vegetation and soil and therefore counteracts the GHG emission reduction [11]. EU policy [4] [12] acknowledges the importance of taking LUC into account but has not yet included it in the sustainability criteria for renewable energy from agricultural products, due to the large uncertainties in its quantification.

Finally, crop and soil management affects not only crop production level and thus gross energy yield, but also 
energy use and GHG emissions of the crop production system. This management is also strongly related to sustainability issues, like avoiding depletion of soil organic matter and maintaining soil fertility. Therefore, crop and soil management is an important factor determining net energy yield and net GHG emission reduction of sustainable bioenergy production chains. Management can also be used to enhance net energy output and net reduction of GHG emission, e.g. by optimising agricultural input levels, such as irrigation and $\mathrm{N}$ fertilisation. So, one of the questions is how crops and soils should be managed, e.g., which levels of irrigation and $\mathrm{N}$ fertilisation should be used for a sustainable maximisation of net outputs of bioenergy production chains (energy, GHG emission reduction). Despite its significance for bioenergy production chains, knowledge of optimal management strategies to achieve these goals is still lacking.

To address these issues, a tool (Energy Crop Simulation Model or E-CROP) has been developed to calculate gross and net energy yield, bioenergy production and GHG emission reduction in a consistent way for various crops, soil types, climatic conditions, agricultural input levels, and energy conversion technologies using a "Well-to-Tank" analysis. This paper describes E-CROP and gives an example of its application by focusing on arable cropping systems in the Netherlands. In this application, the impact of LUC on net GHG emission reduction has not been taken into account.

\section{Methodology}

\subsection{Outline}

In this study guidelines of ISO 14040/44 for Life Cycle Assessment (LCA) have been followed [13] [14]. The goal of the analysis is the evaluation of the effects of different land use and agricultural management options with respect to the potential of energy crops to replace non-renewable (fossil) energy and to reduce GHG emissions. Other environmental impacts, e.g., eutrophication or acidification, have not been assessed. Bioenergy chains based on different cropping systems are compared in a "Well to Tank" analysis with their appropriate fossil reference chains (bioethanol $\rightarrow>$ gasoline from crude oil, biodiesel $\rightarrow>$ diesel from crude oil, bio-electricity $\rightarrow$ power production from a mix of fuels and heat $\rightarrow$ heat production from natural gas). Co-products from the cropping systems and from the biofuel production were either incorporated into the soil following current agricultural practices or converted into additional energy, e.g., electricity, of which the benefits were added to the energy and GHG emission balances. One hectare is chosen as functional unit because agricultural land is one of the limiting resources for crop production, so the output is expressed in either $\mathrm{GJ} \cdot \mathrm{ha}^{-1} \cdot \mathrm{y}^{-1}$ (replaced energy) or $\mathrm{t}$ $\mathrm{CO}_{2}$-eq $\cdot \mathrm{ha}^{-1} \cdot \mathrm{y}^{-1}$ (GHG emission reduction). The production of seeds for the energy crops also occupies land and this has been included by allocating a part of the functional unit to the production of seeds (with crop-specific allocation factors) and using the remaining part ('net hectare') for energy crop production.

The calculations in E-CROP comprise two steps. First, crop yields are simulated as a function of irrigation and $\mathrm{N}$ fertilisation (see 2.2 for a more detailed description). Other inputs, i.e. other nutrients, pesticides and fuel use for farming, are assumed to be either constant or proportional to the calculated crop yields, irrigation and $\mathrm{N}$ input levels. In the second step inputs and outputs of energy and corresponding GHG emissions are calculated for each process (crop production, transport, conversion and distribution; see $2.3 \& 2.4$ ), resulting in an impact assessment on the net reduction in primary (fossil) energy use and GHG emissions. $\mathrm{N}_{2} \mathrm{O}$ emissions were included, but methane $\left(\mathrm{CH}_{4}\right)$ emissions have not been taken into account because its contribution to total GHG emission is usually very small (up to only $2 \%$ in crop production [15]). Due to the regional and timely characteristic of used input data, results of this study are only valid for the Netherlands in the period 2001-2005. However, the methodology is wider applicable through the use of a crop/soil simulation model in E-CROP.

\subsection{Cropping Systems}

Four arable crops were selected for the analysis: potato, sugarbeet, winter oilseed rape and silage maize, each cultivated on two contrasting soil types: a deep rootable clay soil, as commonly found in the northern part of the Netherlands, and a sandy soil with a shallow rootable layer, more typical of the southern part of the Netherlands (Table 1). Maximum rooted depth of the clay soil was a function of the rooting pattern of the crop and ranged from 0.6 to $1.2 \mathrm{~m}$, whereas that of the sandy soil was limited by soil characteristics, and set at $0.4 \mathrm{~m}$ for all crops. It was assumed that maize is grown on the same fieldeach year and that the other bioenergy crops are grown in rotation with common food crops. Calculations for maize on sandy soils further included cultivation of a catch crop during winter, as imposed by regulations on $\mathrm{N}$ management in the Netherlands. 
Table 1. Input choices on crops and soils used in the analysis (N: nitrogen, DM: dry matter).

\begin{tabular}{|c|c|c|c|c|}
\hline Crops $^{\mathrm{a}}$ & Growth period & $\begin{array}{l}\text { Water storage } \\
\text { capacity }^{\text {b }}(\mathrm{mm})\end{array}$ & $\begin{array}{l}\text { Maximum } \mathrm{N} \text { input level }{ }^{\mathrm{c}} \\
\left(\mathrm{kg} \cdot \mathrm{N} \cdot \mathrm{ha}^{-1}\right)\end{array}$ & $\begin{array}{c}\text { Yield }^{\mathrm{d}} \\
\left(\mathrm{t} \cdot \mathrm{DM} \cdot \mathrm{ha}^{-1}\right)\end{array}$ \\
\hline $\begin{array}{l}\text { Potato } \\
\text { (tubers) }\end{array}$ & April - September & $\begin{array}{c}71 \\
172\end{array}$ & 250 & $\begin{array}{c}10.5 \\
9.2\end{array}$ \\
\hline $\begin{array}{l}\text { Sugar beet } \\
\text { (roots) }\end{array}$ & April - October & $\begin{array}{c}71 \\
345\end{array}$ & 150 & $\begin{array}{l}13.7 \\
13.4\end{array}$ \\
\hline $\begin{array}{l}\text { Winter oilseed rape } \\
\text { (seeds) }\end{array}$ & September - July & $\begin{array}{c}71 \\
359\end{array}$ & 200 & $\begin{array}{l}2.9 \\
3.1\end{array}$ \\
\hline $\begin{array}{l}\text { Silage maize } \\
\text { (whole plant) }\end{array}$ & May - October & $\begin{array}{c}71 \\
287\end{array}$ & 180 & $\begin{array}{l}13.9 \\
13.8\end{array}$ \\
\hline
\end{tabular}

${ }^{a}$ Note that the harvested part is not the same for the different crops and that silage maize was harvested excluding roots and a short aboveground stubble. ${ }^{b}$ Water storage capacity was defined by the maximum amount of water that can be stored in the rooted zone between field capacity and permanent wilting point. First value of each crop refers to the sandy soil $(71 \mathrm{~mm})$ and second value to the clay soil $(172-359 \mathrm{~mm}) .{ }^{~} \mathrm{Effective} \mathrm{N}$ application from mineral fertilisers and manures as proposed for 2007/2009 according to Dutch legislation in 2006, averaged for clay and sandy soils (differences in the values between both soil types do not exceed $10 \mathrm{~kg} \cdot \mathrm{N} \cdot \mathrm{ha}^{-1}$ ). ${ }^{\mathrm{d}}$ Average farmer's yields in the southern (first value) and northern (second value) part of the Netherlands according to national (fresh) yield statistics from 2001-2005 [20] and the following DM percentages: 20\% (potato), 23\% (sugar beet) and $91 \%$ (oilseed rape). Silage maize yields were reported in dry matter units.

Water and $\mathrm{N}$ availability to the crops were varied to simulate a number of alternative production scenarios for each combination of crop and soil type. Three irrigation levels were defined: high (HI), medium (MI), arbitrarily set at approximately 50\% of HI, and zero irrigation (ZI). The amount of irrigation water supplied at HI was calculated by a dynamic crop growth model which is part of E-CROP and differed among crops and soils (see explanation below). For every combination of crop, soil and irrigation nine $\mathrm{N}$ input scenarios were defined for which two types of $\mathrm{N}$ input sources were used: pig manure (the most probable option in the Netherlands) and mineral fertiliser. Three manure input levels were selected and each level was supplemented with three mineral fertiliser levels. All N input scenarios comply with Dutch regulations in 2006 concerning the use of animal manure and the application of total effective $\mathrm{N}$ [16].

The relation between irrigation and crop dry matter (DM) yield was determined by using the ROTASK crop growth model [17], as function of daily weather data, soil and crop characteristics with other growth-affecting factors assumed non-limiting. The weather data were obtained from a weather station in the centre of the Netherlands (period: 1985-1999). The model was run for each year and average values from the calculations were used to determine arelation between irrigation and crop DM yield (see Figure 1(a) for a schematic illustration).

Next, empirical response curves [18] were used to calculate crop DM yields for the selected N input levels (Figure 1(b)) under the condition that $\mathrm{N}$ inputs (deposition and fertilisation) and outputs (harvest and losses) of the crop/soil system were matched, in order to maintain soil $\mathrm{N}$ fertility [19]. [18] contains $\mathrm{N}$ response curves for all selected crops, except winter oilseed rape. For this crop, the winter wheat curve was used, as growth period and fertilisation practices of both crops are similar, after adjusting the yield levels.

Finally, calculated crop DM yields were calibrated with Dutch yield statistics [20] to represent average yields from Dutch farms (Table 1). For each combination of crop and soil type one calibration factor was determined by taking the ratio of reported yield from Table 1 to the calculated yield at the same fertilization level and applied to all calculated DM yields of this combination. This resulted in decreases ranging from $1 \%$ to $25 \%$ for the crops and soil types used in this analysis, which is similar to differences usually found in the Netherlands between average yield levels of commercial farming and those obtained from well-managed experimental fields under good growing conditions. It was assumed that maize was stored on-farm (see 2.3), causing a 5\% loss in gross maize DM yield.

\subsection{Energy Balance}

Biofuel production was chosen as the basic conversion process for potato, sugar beet and oilseed rape, whereas maize was supposed to be used for the production of electricity through on-farm anaerobic digestion. Furthermore, extra energy production from the process residues of biofuel production was calculated, using anaerobic digestion for moist products (residues from bioethanol production) and co-combustion for dry products (residues from biodiesel production). Crop by-products, like sugar beet leaves and oilseed rape straw, were not included in the energy production in this analysis, because in (Dutch) practise they are mostly left at the field for soil incorporation. 


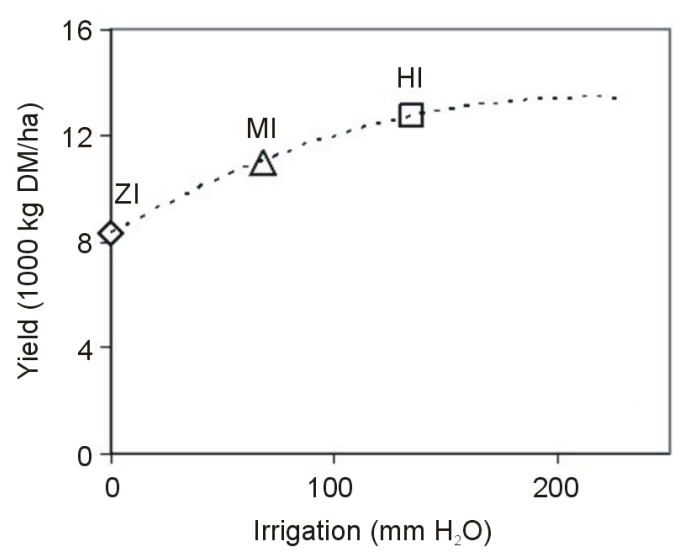

(a)

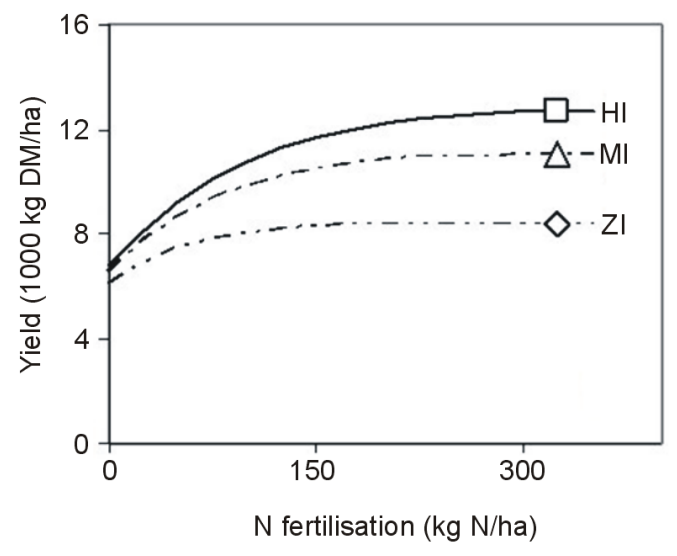

(b)

Figure 1. Illustration of the calculation method: (a) Selection of three points from the relationship between irrigation and crop DM yield under conditions of ample nutrient supply, and (b) Using the selected DM yields as maximum yield levels in the relationship that defines the response of crop DM yield to $\mathrm{N}$ fertilisation (HI: high irrigation, MI: medium irrigation and ZI: zero irrigation level).

Gross energy yield was defined as the amount of primary fossil energy that can be replaced by the bioenergy produced and was calculated from crop DM yield using standard values for energy content of the different agricultural products, conversion efficiencies and data on the (in)direct energy content of fossil-based energy carriers (Table 2 \& Table 3). Bioenergy was assumed to replace fossil net energy on an equal energy basis (1 MJ $\mathrm{MJ}^{-1}$ ) and gross energy yield also includes the difference between gross and net energy in Table 3 which reflects the energy use in the fossil reference chain from "Well to Tank". The conversion efficiency for calculating residual heat from anaerobic digestion (Table 2) is excluding the heat used to optimise the temperature of the digestion process (residual heat equals $60 \%$ of total heat produced).The residual heat from the anaerobic digestion of the residues of bioethanol production was included in the gross energy yield, because it can be used efficiently in the bioethanol distillation process. Contrary, it was excluded from the gross energy yield in the situation of maize, because maize was assumed to be digested in a small on-farm installation where normally only a small part of the residual heat can be used. Residues of biodiesel production were assumed to be burnt in a large co-combustion installation, which produces electricity in the most efficient way, but the residual heat produced is normally not used and was therefore also not taken into account in the gross energy yield.

Net energy yield was defined as the difference between gross energy yield and the sum of direct and indirect energy use from each process in the bioenergy production chain. Energy use in crop production was partly considered to be a standard value determined by crop and soil type, e.g. related to seed production, soil tillage, pesticide production and spraying, etc., and partly proportional to fertiliser and water input levels, and to crop DM yield, e.g. for on-farm drying and storage. Parameters used are mainly from Dalgaard et al. [21] and Dutch statistical data on direct energy use in Dutch agriculture [22]. Energy use during crop transport was calculated from harvested crop biomass and transport distances, which were set at $50 \mathrm{~km}$ for potato, sugar beet and oilseed rape (distance between farm and biofuel industry) and $0 \mathrm{~km}$ for maize, because maize was supposed to be digested on-farm. Parameters for energy use during conversion processes were derived from [23] and [24], while energy use during distribution was calculated as in [25]. For potato no references are available and the conversion efficiency was estimated on the basis of an average starch content and the energy use during the conversion process was estimated to be comparable with sugar beet. Conversion efficiencies of anaerobic digestion were taken from [26].

It was assumed that application of pig manure to energy crops competes with application to other (non-energy) crops elsewhere. Hence, energy use and GHG emissions of equivalent amounts of a mineral fertiliser were attributed to manure. Usually, manure will not be produced on the farm where the energy crops are grown and thus requires transport to this farm. Because most pig farms are located in the South of the Netherlands, the transport distance was set at $10 \mathrm{~km}$ for the South and at $200 \mathrm{~km}$ for the North of the Netherlands. It was assumed that the effluent of anaerobic digestion was used to replace manure and/or mineral fertiliser on the same farm. The mineral fertiliser equivalent of the effluent, the weight transported and the distance between digestion 
Table 2. Energy contents of different agricultural products, energy use and conversion efficiencies of energy conversion processes.

\begin{tabular}{|c|c|c|c|c|}
\hline \multirow{2}{*}{ Product } & \multirow{2}{*}{$\mathrm{MJ} \cdot \mathrm{kg}^{-1} \cdot \mathrm{DM}$} & \multirow{2}{*}{ Process } & \multicolumn{2}{|c|}{ MJ energy/MJ agricultural product } \\
\hline & & & Energy use & Conversion efficiency \\
\hline Potato tubers & 17.0 & $\begin{array}{l}\text { Bioethanol production } \\
\text { Anaerobic digestion }^{\mathrm{a}}\end{array}$ & $\begin{array}{c}0.22 \\
0.019\end{array}$ & $\begin{array}{l}0.610 .065^{\mathrm{b}} \\
0.094^{\mathrm{c}} 0.58\end{array}$ \\
\hline Sugar beet roots & 17.0 & $\begin{array}{l}\text { Bioethanol production } \\
\text { Anaerobic digestion }^{\mathrm{a}}\end{array}$ & $\begin{array}{c}0.21 \\
0.016\end{array}$ & $\begin{array}{l}0.056^{\mathrm{b}} 0.08^{\mathrm{c}} \\
0.550 .135^{\mathrm{b}}\end{array}$ \\
\hline Oilseed rape seeds & 27.6 & $\begin{array}{l}\text { Biodiesel production } \\
\text { Co-combustion }^{\mathrm{a}}\end{array}$ & $\begin{array}{c}0.16 \\
0.025\end{array}$ & $\begin{array}{l}0.168^{\mathrm{c}} \\
0.25^{\mathrm{b}}\end{array}$ \\
\hline Silage maize & 17.0 & Anaerobic digestion & 0.073 & $0.36^{\mathrm{c}}$ \\
\hline
\end{tabular}

${ }^{\mathrm{a}}$ Anaerobic digestion and co-combustion of residues of the biofuel production. ${ }^{\mathrm{b}}$ Electricity. ${ }^{\mathrm{c}}$ Residual heat.

Table 3. Energy contents of energy carriers and GHG emission factors.

\begin{tabular}{|c|c|c|c|c|}
\hline & $\begin{array}{l}\text { Net energy } \\
\text { content }\end{array}$ & $\begin{array}{l}\text { Gross energy }^{\mathrm{a}} \\
\text { content }\end{array}$ & $\begin{array}{c}\mathrm{CO}_{2} \text { emission }^{\mathrm{b}} \\
\left(\mathrm{kg} \cdot \mathrm{GJ}^{-1}\right)\end{array}$ & $\begin{array}{c}\mathrm{N}_{2} \mathrm{O} \text { emission } \\
\left(\mathrm{kg} \mathrm{CO}_{2}-\mathrm{eq} \cdot \mathrm{kg}^{-1} \cdot \mathrm{N}\right)\end{array}$ \\
\hline Diesel & 43.3 & 50.2 & 86.1 & \\
\hline Gasoline & 43.7 & 53.3 & 87.8 & \\
\hline Electricity & 3.6 & 9.5 & 156 & \\
\hline Natural gas & 31.65 & 32.0 & 56.6 & \\
\hline Biodiesel & 37.0 & & & \\
\hline Bioethanol & 26.8 & & & \\
\hline \multicolumn{5}{|l|}{ Fertiliser } \\
\hline Direct soil emission & & & & 4.87 \\
\hline Indirect soil emission & & & & 1.58 \\
\hline Production emission & & & $2.11^{c}$ & 3.18 \\
\hline \multicolumn{5}{|l|}{ Crop residues } \\
\hline Direct soil emission & & & & 4.87 \\
\hline Indirect soil emission & & & & 1.09 \\
\hline
\end{tabular}

${ }^{\mathrm{a}}$ Energy content of (bio)diesel, gasoline and bioethanol in $\mathrm{MJ} \cdot \mathrm{kg}^{-1}$, electricity in $\mathrm{MJ} \cdot \mathrm{kWh}^{-1}$ and natural gas in $\mathrm{MJ} \cdot \mathrm{m}^{-3}$; gross energy content includes indirect energy. ${ }^{\mathrm{b}} \mathrm{Sum}$ of combustion emission and indirect emissions per GJ net energy content. ${ }^{\mathrm{c}} \mathrm{kg} \mathrm{CO}_{2} \cdot \mathrm{kg}^{-1} \cdot \mathrm{N}$.

installation and farm (50 km for potato and sugar beet, and $0 \mathrm{~km}$ for maize) were used to calculate its contribution to the energy and GHG emission balances.

\subsection{GHG Emissions}

The calculation of the GHG balance takes three steps. First, a reduction in $\mathrm{CO}_{2}$ emission was assessed by the amounts of fossil energy that can be replaced by the produced bioenergy and specific $\mathrm{CO}_{2}$ emission factors [23] [27] (see Table 3). Second, this reduction was corrected for the $\mathrm{CO}_{2}$ emissions due to the total energy use during crop production, transport, conversion and distribution of bioenergy. Here, the combustion emission factor of diesel $\left(74.3 \mathrm{~kg} \cdot \mathrm{CO}_{2} \cdot \mathrm{GJ}^{-1}\right)$ was used as a reasonable average for the variable mix of actually used energy sources. An exception was made for the $\mathrm{CO}_{2}$ emission in fertiliser production, for which a lower emission factor was used [28] (see Table 3). Third, the reduction in GHG emission was calculated from the net reduction in $\mathrm{CO}_{2}$ emission minus the direct and indirect emissions of $\mathrm{N}_{2} \mathrm{O}$ due to use of $\mathrm{N}$ fertiliser, following IPCC-2006 guidelines [29]. $\mathrm{N}_{2} \mathrm{O}$ emission from $\mathrm{N}$ fertiliser use in the production of seed for the energy crops has been taken into account as well.

\section{Results}

The results of the calculations are presented in detail in Tables 4-6 for a standard situation, whereas for the wider spectrum of growth conditions results are summarised in Figures 2-4. The standard situation for all crops was the sandy soil in the South of the Netherlands, in combination with the maximum allowed N input from fer- 
tilisation and the medium irrigation level (MI). For potato, sugar beet and silage maize the maximum allowed amount of manure was used, for oilseed rape no manure was used. These situations generally comply with the average agricultural practice in the South of the Netherlands during 2001-2005.

\subsection{Gross and Net Energy Yield in the Standard Situation}

The calculated gross energy yield (Table 4) was highest for sugar beet and lowest for oilseed rape with a significant contribution from the energy of the process residues, ranging from 25\% (sugar beet) to 35\% (oilseed rape). Especially in the case of silage maize, the calculated gross energy yield was relatively low compared to its crop DM yield due to the exclusion of the residual heat.

For calculating the net energy yield, the use of energy in the four main processes of the bioenergy production chains has been determined (Table 5). Energy use in crop production was relatively high for potato due to intensive soil tillage, frequent application of agro-chemicals, high $\mathrm{N}$ fertilisation, and high energy use in harvesting. Irrigation in the standard situation (MI irrigation level) amounted to about $10 \%$ to $20 \%$ of the total agricultural energy use, whereas $\mathrm{N}$ fertilisation accounted for about $50 \%$ to $60 \%$. Highest transport energy use was found for potato and sugar beet due to their high DM yields and water contents in the crop product. Energy use in the conversion processes of potato and sugar beet was higher compared to the other two crops because ethanol distillation requires much energy. Total energy use equalled 20\% (maize) to $43 \%$ (potato and oilseed rape) of the gross energy yield. Net energy yield in the standard situation (Table 6) was lowest for oilseed rape due to its relatively low DM yield and highest for sugar beet (high gross energy yield) and maize (low energy use).

Table 4. Bioenergy production and gross energy yield, i.e. amount of replaced fossil energy, by energy crops in the standard situation.

\begin{tabular}{cccccc}
\hline Crop & $\begin{array}{c}\text { Bioethanol } \\
\left(\mathrm{t} \cdot \mathrm{ha}^{-1}\right)\end{array}$ & $\begin{array}{c}\text { Biodiesel } \\
\left(\mathrm{t} \cdot \mathrm{ha}^{-1}\right)\end{array}$ & $\begin{array}{c}\text { Electricity } \\
\left(\mathrm{MWhha}^{-1}\right)\end{array}$ & $\begin{array}{c}\text { Heat }^{\mathrm{a}} \\
\left(\mathrm{GJ} \cdot \mathrm{ha}^{-1}\right)\end{array}$ & $\begin{array}{c}\text { Gross energy yield } \\
\left(\mathrm{GJ} \cdot \mathrm{ha}^{-1}\right)\end{array}$ \\
\hline Potato & 4.09 & & 3.25 & 16.7 & $183^{\mathrm{b}}$ \\
Sugar beet & 4.99 & & 3.65 & 18.8 & $219^{\mathrm{b}}$ \\
Oilseed rape & & 1.20 & 3.01 & 14.6 & $80^{\mathrm{c}}$ \\
Silage maize & & 15.9 & 81.5 & $151^{\mathrm{c}}$ \\
\hline
\end{tabular}

${ }^{\mathrm{a}}$ Residual heat from electricity production. ${ }^{\mathrm{b}}$ Residual heat included, where the amount of replaced fossil energy was estimated by assuming that natural gas is used in producing heat with an efficiency of $90 \%$. ${ }^{\circ}$ Residual heat excluded.

Table 5. Energy use in the bioenergy production chains in the standard situation.

\begin{tabular}{cccccc}
\hline Crop & $\begin{array}{c}\text { Crop production } \\
\left(\mathrm{GJ}_{\mathrm{h}} \mathrm{C}^{-1}\right)\end{array}$ & $\begin{array}{c}\text { Transport } \\
\left(\mathrm{GJ} \cdot \mathrm{ha}^{-1}\right)\end{array}$ & $\begin{array}{c}\text { Conversion } \\
\left(\mathrm{GJ} \cdot \mathrm{ha}^{-1}\right)\end{array}$ & $\begin{array}{c}\text { Distribution }^{\mathrm{a}} \\
\left(\mathrm{GJ} \cdot \mathrm{ha}^{-1}\right)\end{array}$ & $\begin{array}{c}\text { Total } \\
\left(\mathrm{GJ} \cdot \mathrm{ha}^{-1}\right)\end{array}$ \\
\hline Potato & 25.9 & 7.4 & 42.8 & 2.0 & 78 \\
Sugar beet & 22.2 & 8.3 & 46.6 & 2.5 & 80 \\
Oilseed rape & 17.0 & 0.7 & 15.8 & 1.2 & 35 \\
Silage maize & 13.3 & 0 & 16.3 & - & 30 \\
\hline
\end{tabular}

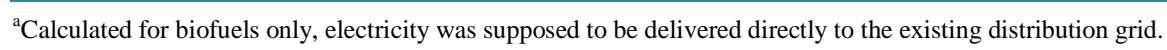

Table 6. Net energy yield and net GHG emission reduction from energy crops in the standard situation.

\begin{tabular}{|c|c|c|c|c|}
\hline Crop & $\begin{array}{l}\text { Net energy yield } \\
\left(\mathrm{GJ} \cdot \mathrm{ha}^{-1}\right)\end{array}$ & $\begin{array}{l}\text { Net reduction in } \\
\mathrm{CO}_{2} \text { emission } \\
\left(\mathrm{t} \mathrm{CO}_{2} \mathrm{ha}^{-1}\right)\end{array}$ & $\begin{array}{l}\text { Increase in } \\
\mathrm{N}_{2} \mathrm{O} \text { emission } \\
\left(\mathrm{t} \mathrm{CO} \mathrm{CO}_{2} \text {-eq } \cdot \mathrm{ha}^{-1}\right)\end{array}$ & $\begin{array}{l}\text { Net reduction in GHG } \\
\text { emission } \\
\text { (t CO } \text { COeq }^{-1} \text { ) }\end{array}$ \\
\hline Potato & 105 & 6.01 & 2.53 & 3.48 \\
\hline Sugar beet & 139 & 9.01 & 2.48 & 6.53 \\
\hline Oilseed rape & 45 & 2.89 & 2.33 & 0.56 \\
\hline Silage maize & 121 & 6.27 & 1.64 & 4.63 \\
\hline
\end{tabular}



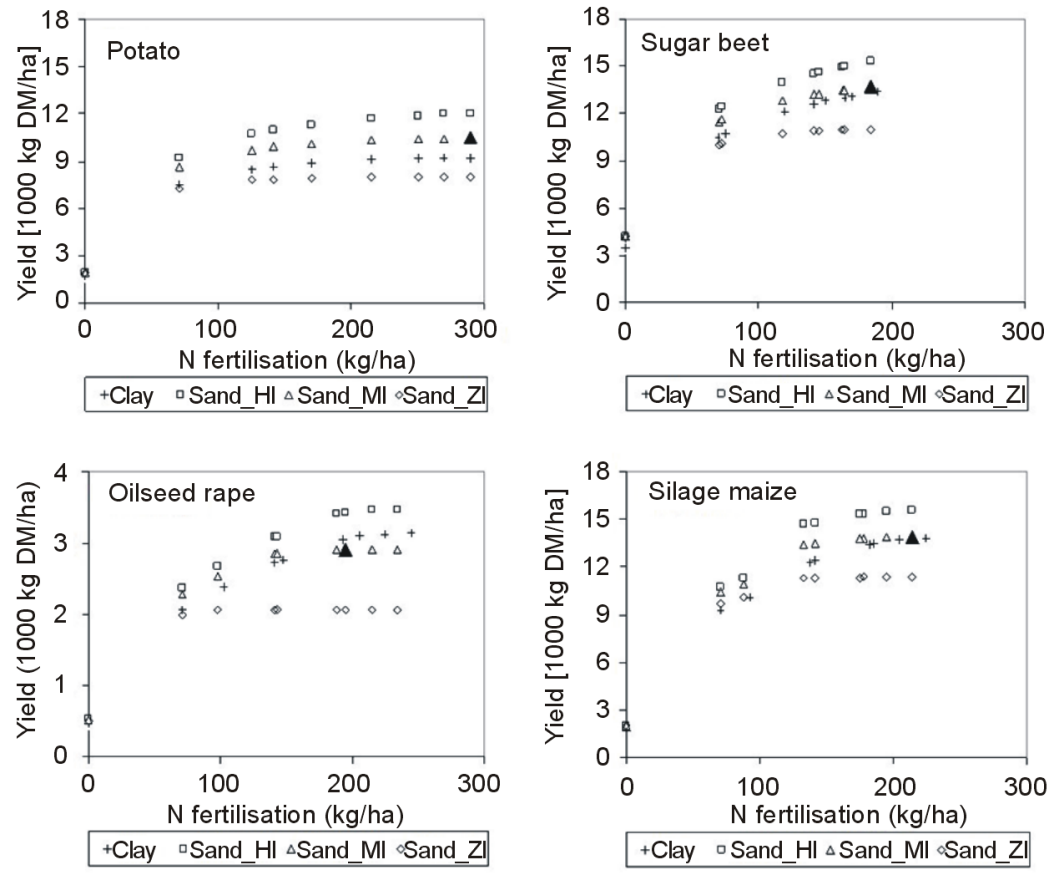

Figure 2. Calculated crop DM yields as a function of $\mathrm{N}$ fertilisation for two soil types at different irrigation levels $(\mathrm{HI}=$ high, $\mathrm{MI}=$ medium and $\mathrm{ZI}=$ zero irrigation level; see text for clarification). $\mathrm{N}$ fertilisation includes $\mathrm{N}$ input from mineral fertilisers and the short + long-term fertiliser $\mathrm{N}$ equivalent of manure inputs. Black triangles represent a standard situation based on average values of current commercial farming in the Netherlands. Note the different scale of the Y-axis of oilseed rape.
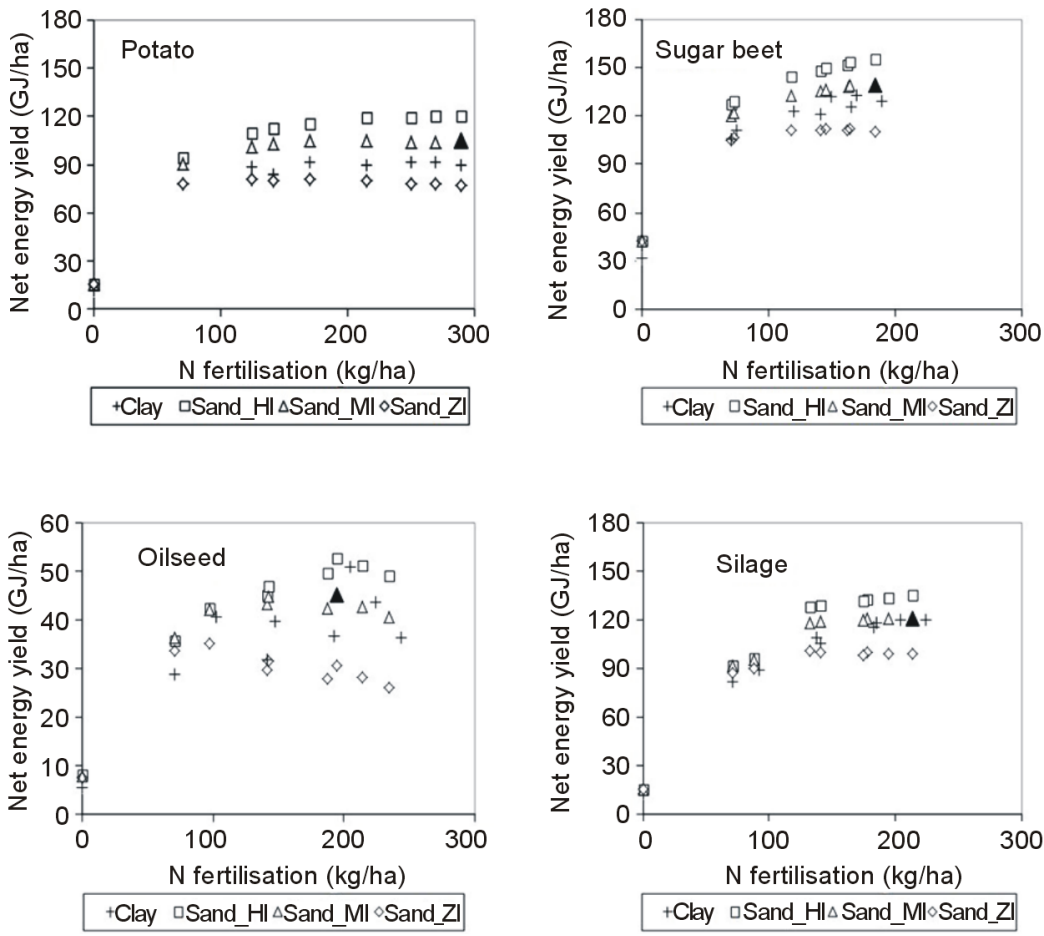

Figure 3. Calculated net energy yields, expressed as amount of replaced fossil energy, as a function of $\mathrm{N}$ fertilisation for different soils and irrigation levels, based on the crop DM yields from Figure 2 (see legend Figure 2 for further clarification). 

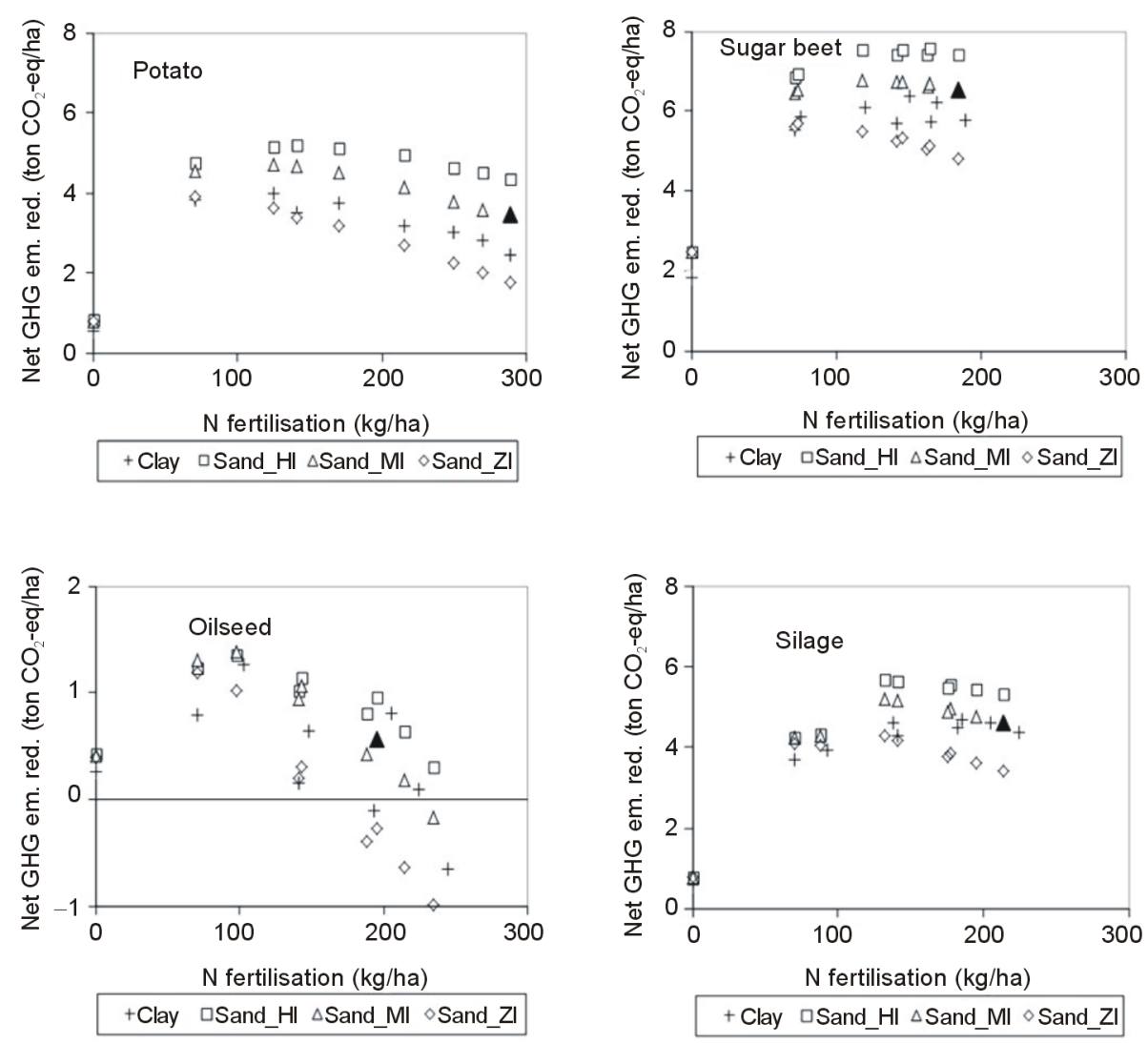

Figure 4. Calculated net reduction in GHG emission as a function of $\mathrm{N}$ fertilisation for different soils and irrigation levels, based on the crop DM yields from Figure 2 (see legend Figure 2 for further clarification).

\subsection{GHG Emission Reduction in the Standard Situation}

Net reductions in $\mathrm{CO}_{2}$ emission were roughly proportional to net energy yields (Table 6). Only small differences in the ratio of net $\mathrm{CO}_{2}$ emission reduction to net energy yield were calculated between bioenergy production chains due to different proportions of electricity and utilised heat in the energy yields Fossil-based electricity and heat emit relatively low amounts of $\mathrm{CO}_{2}$ per unit of fossil energy used [27], resulting in a lower $\mathrm{CO}_{2}$ emission reduction of electricity or heat produced from biomass. Besides $\mathrm{CO}_{2}$ emissions, energy crop production causes $\mathrm{N}_{2} \mathrm{O}$ emissions through the use of $\mathrm{N}$ fertiliser and the incorporation of $\mathrm{N}$ with crop residues in the soil. Lowest $\mathrm{N}_{2} \mathrm{O}$ emissions were calculated for maize due to relatively low $\mathrm{N}$ inputs with fertiliser and crop residues associated with recycling of the effluent and whole crop harvesting. Cultivation of the other crops resulted in higher $\mathrm{N}_{2} \mathrm{O}$ emissions due to high fertiliser $\mathrm{N}$ application level (potato and oilseed rape) and high crop residue $\mathrm{N}$ content (sugar beet). The $\mathrm{N}_{2} \mathrm{O}$ emission had a large impact on the resulting net GHG emission reductions. The ratio of net reduction in GHG emission to net reduction in $\mathrm{CO}_{2}$ emission ranged from $19 \%$ (oilseed rape) to $58 \%$ (potato), $73 \%$ (sugarbeet) and $74 \%$ (maize).

\subsection{Response of Crop DM Yield to N Fertilisation and Irrigation}

In general calculated crop DM yield responded positively to $\mathrm{N}$ fertilisation up to a certain plateau and also irrigation had a positive effect on crop DM yields, except on the clay soil for sugar beet, oilseed rape and maize where the irrigation effect was nil. Yield of irrigated potato on the clay soil was increased (due to its shallow rooting depth), but for reasons of similarity with the other three crops, only non-irrigated yields on the clay soil are presented in this paper (Figure 2). There was a positive interaction between both inputs, as in most situations the input use efficiency of an input (kg DM yield increase per extra kg input) was larger at higher levels of the other input. 


\subsection{Effects of N Fertilisation and Irrigationon Net Energy Yields and GHG Emission Reduction}

Net energy yield was also positively correlated to $\mathrm{N}$ fertilisation, but unlike the response of DM yield a decline occurred in some situations at higher $\mathrm{N}$ input levels because the extra energy use was no longer compensated by the extra energy production from crop biomass (especially for oilseed rape and at low irrigation levels; Figure 3). For the net GHG emission reduction this effect was even more pronounced (Figure 4), due to the $\mathrm{N}_{2} \mathrm{O}$ emission of fertilizer use. The $\mathrm{N}$ fertilisation needed to realise maximum results was therefore lower for net GHG emission reduction than for net energy yield and dry matter yield, respectively. Especially in potato and oilseed rape, i.e. the crops with lowest net energy yields but highest $\mathrm{N}$ input levels, the difference in optimum $\mathrm{N}$ fertilisation was large.

Irrigation resulted in higher net energy yield and net GHG emission reduction, due to the favourable ratio between energy used for irrigation and associated dry matter increase, except for the lowest $\mathrm{N}$ fertilisation levels on the sandy soil (Figure 3).

\section{Discussion}

\subsection{Crop DM Yield Levels}

The maximum crop DM yields in our analysis are similar to those from other studies investigating the use of crops for energy production (e.g. [23]), but higher yield shave also been frequently reported in literature. However, in most situations these higher yields either refer to experimental field conditions (e.g. winter oilseed rape: $4.5 \mathrm{t} \cdot \mathrm{DM} \cdot \mathrm{ha}^{-1}$ [30]; silage maize: more than $20 \mathrm{t} \cdot \mathrm{DM} \cdot \mathrm{ha}^{-1}$ [31]), where on average higher yields can be obtained than in commercial farming, or to expectations of future developments of crop yield and management (e.g. sugar beet: $20 \mathrm{t} \cdot \mathrm{DM} \cdot \mathrm{ha}^{-1}$ [10]; winter oilseed rape: $5.3 \mathrm{t} \cdot \mathrm{DM} \cdot \mathrm{ha}^{-1}$ [8]). In our analysis average crop DM yields of Dutch farms were chosen as maximum output of the agricultural system, including the $\mathrm{N}$ use restrictions from environmental legislation. Likewise, only efficiencies of readily available energy conversion routes were used (Table 2) and future improvements in the conversion of biomass into energy were not included. This means that our results refer to current conditions and should be valued as conservative estimates for the future, where improvements in both cropping systems and process technologies may enhance net output e.g. [32]. However, stagnation in crop yield development, possibly caused by e.g. more stringent environmental legislation on $\mathrm{N}$ use (e.g. EU Water Framework Directive [33]) or adverse weather conditions for crop growth due to climate change (such as more frequent periods of drought or rain storms) cannot be ruled out. For estimating future yield levels of energy crops a number of issues should simultaneously be taken into account, ranging from crop genetic improvements, effects of expected climate change, adapted agricultural management and future environmental constraints. Integration of these issues is necessary and crop growth models, as applied in E-CROP, can be used to explore scenarios and investigate the conditions for possible yield improvements.

\subsection{Net Energy Yield}

With proper crop management, positive net energy yields were calculated for all bioenergy production chains (Figure 3), which implies that fossil energy can be replaced by growing arable crops for energy production. This is in agreement with work by others [7] [23] [34], although the net results in the various publications, including this one, differ slightly due to a variety of reasons.These reasons range from differences in crop DM yield, $\mathrm{N}$ input use, agricultural energy use, transport distances to energy conversion factors and the use of by-products, but all papers conclude that a significant positive energy balance is possible.

In our analysis the energy production from the process residues of potato, sugar beet and oilseed rape significantly contributed to the results.Net energy yield gained 50,52 and $26 \mathrm{GJ} \mathrm{ha}^{-1}$ from potato, sugar beet and oilseed rape residues, respectively, equal to $48 \%, 37 \%$ and $58 \%$ of net energy yield of Table 6 . The effluent from the anaerobic digestion process replaced manure and/or mineral fertiliser input to the crop in our analysis of which the energy savings outweighed the energy use from transporting and applying the effluent. The largest contribution from recycling the effluent was calculated for silage maize, where net energy yield was increased by $10 \mathrm{GJ} \cdot \mathrm{ha}^{-1}$.

In literature the value of residues (e.g. process residues) for the net energy balance is treated in different ways. One is allocating part of the energy use to the residues, by using the economic value or the caloric energy value 
of the various products in the chain as weighing factor e.g. [23] [24]. With this method the focus is on the main product of the bioenergy chain for which a (partial) energy balance is determined by excluding the residues. In fact, the residues are treated as part of other (non-energy) chains (e.g. feed for animal production) in which the allocated energy use from the bioenergy chain and possible extra processing to make the residue suitable should be taken into account. Therefore, this method does not give the total effect of growing bioenergy crops on the replacement of fossil energy, because the total effect of residues is not determined. A principle better way is the system expansion approach as used in LCA [13] [14], in which the net energy value of a residue is valued by assessing the net energy value of another product that can be replaced by the residue. Then, the amount of energy saved by this replacement is added as a credit to the total energy balance of the bioenergy chain and an allocation of energy use among the various products is no longer needed. For the system expansion approach choices on the use of the residues are still required. E.g. in [7] one of the residues was used as animal feed and thus replaced the production of an equivalent amount of a specified other crop used for animal feeding. They have based their choices with respect to the use of the residues and the alternative systems on current practices in their region. In our work, in which we also applied the system expansion approach, the residues were used to produce energy with alternative systems of fossil-based electricity and heat production under current Dutch conditions. We realise that this choice does not reflect the actual practice of today, but assume that it gives a good estimate of the total potential replacement of fossil energy by bioenergy crops which was one of the goals of our analysis.

Net energy yields of potato, sugar beet and oilseed rape would have been higher if crop by-products (leaves and straw) were used for energy production. However, these by-products were assumed to be incorporated into the soil and contribute to maintaining the organic matter level in the soil. We have not calculated the soil carbon dynamics in this analysis, because this would require information about the management of other crops besides the three crops which we have investigated (potato, sugar beet and oilseed rape). These other crops are necessary to complete a whole rotation at which the soil carbon balance should be investigated. Any differences in the soil carbon storage due to growing the energy crops are thus not taken into account. Changes in soil carbon storage may alter the net GHG emission reduction, although only temporarily until a new equilibrium in carbon storage has been reached. Beside this effect of carbon storage, the level of soil organic matter can also affect soil management and/or crop growth. If all aboveground biomass of an energy crop would be harvested to maximise energy yield, soil organic matter levels will stabilise at a lower level, which may have negative consequences for crop DM yield levels as function of agricultural inputs, such as irrigation and $\mathrm{N}$ fertilisation. More inputs will probably be needed to achieve the same crop yields or the same input level will probably result in lower crop yields, as compared to the situation with a higher soil organic matter level. Depending on local weather conditions and soil characteristics, this feedback may continue to affect the input-output relations of crop production in the future contrary to the carbon storage after reaching equilibrium.

\subsection{GHG Emission and Optimisation of N Fertiliser Input Level}

The emission of $\mathrm{N}_{2} \mathrm{O}$ results in a substantially lower net to gross GHG emission reduction ratio compared to the net to gross energy yield ratio and hence, bioenergy is more effective in avoiding fossil energy use than in mitigating GHG emission in our analysis. Sugar beet was the best performing bioenergy crop to reduce GHG emissions, mainly due to its favourable ratio of crop DM yield vs. $\mathrm{N}$ input demand, whereas this is the opposite for oilseed rape in which even an GHG emission increase was calculated in a number of situations. However, these situations can be characterised as over-fertilised because the extra $\mathrm{N}$ input did not produced more crop dry matter (Figure 2) and as such should be viewed as non-proper $\mathrm{N}$ management.

Maximum allowed $\mathrm{N}$ fertilisation levels in this analysis were based on the economic optimum level for food crop production in the Netherlands and were slightly reduced by environmental restrictions to comply with the EU Nitrate Directive [35]. Application of these $\mathrm{N}$ fertilisation levels resulted in the maximum yields of our analysis with respect to gross crop DM and gross energy. However, $\mathrm{N}$ fertilisation is also an important source of energy use and GHG emission, and the optimal N fertilisation levels for maximum net energy yields and especially GHG emission reductions appeared to be lower than the maximum allowed $\mathrm{N}$ input levels for a number of combinations of crop, soil and irrigation levels. In these situations the maximum values for net energy yield and GHG emission reduction were thus already reached at sub-optimal gross energy yield levels. It is therefore important that targets of energy crop production in terms of either net energy yield or GHG emission reduction are 
defined beforehand with an appropriate adjustment of the $\mathrm{N}$ fertilisation level for optimising the result. Especially when net GHG emission reduction is set as main target, farmers should significantly reduce their fertilisation to levels that are sub-optimal for crop growth, which consequently leads to lower gross and net energy yields. E.g. on the sandy soil with medium irrigation level, the $\mathrm{N}$ fertilization with the highest calculated net GHG emission reduction ranges from circa 50\% (oilseed rape, potato) to $74 \%$ (silage maize) and $79 \%$ (sugar beet) of the maximum $\mathrm{N}$ input level from Table 1 . These fertilisation levels may be increased through irrigation. However, using sub-optimal fertilization levels leads to lower financial returns if farmers are paid proportional to the amount of produced crop biomass. Thus, aiming for the highest GHG emission reduction would require a payment scheme that links the financial returns to the achieved reduction level. Results of this analysis clearly show the importance of crop and soil management, i.e., irrigation and $\mathrm{N}$ fertilisation, for optimising the outputs of bioenergy production chains.

\subsection{Use of E-CROP}

In this analysis E-CROP is used for evaluating specific bioenergy production chains by comparing the results of a number of crops, soil types, agricultural input levels, and energy conversion routes in a consistent way. Other situations can easily be incorporated, and P demands can be determined as well. E-CROP is a flexible tool, especially useful for ex-ante evaluation of alternative options for energy production from crops and can be applied to different growing conditions. Most other analyses or tools in this field either focus on a limited number of crops (e.g. [7]) or have not incorporated the possibility of optimising agricultural management (e.g. [23] [36]). Production sustainability of the used cropping systems has explicitly been treated in E-CROP, but so far only with respect to the soil $\mathrm{N}$ balance. Other aspects of sustainable cropping systems should be addressed as well, such as a soil organic matter balance. Cropping systems used for energy production can then be checked for sustainability with respect to the soil carbon pool and if carbon loss from soil organic matter occurs, it can be taken into account in determining the net GHG emission reduction of bioenergy production chains.

\section{Conclusion}

Arable crops can be grown in the Netherlands for energy production to reduce fossil energy use, because the energy balance can be positive (more energy produced than consumed in the whole process). Growing arable crops for energy production can also reduce GHG emission in most situations. These conclusions are based on calculations for a variety of arable crops and energy carriers. Where arable crops are grown with the purpose of replacing fossil energy or reducing GHG emissions, crop management should be critically re-evaluated, because goals have changed from food production to net energy production and/or GHG emission reduction. The analysis of this paper made clear that the cropping conditions, resulting from crop choice, input use, soil type and also climatic conditions, influence the performance of the whole system and that knowledge of agricultural systems is needed for optimisation with respect to the "new" goals (net energy yield and GHG emission reduction). On top of that, it became obvious that not all goals can be simultaneously optimised (e.g. using mineral $\mathrm{N}$ fertiliser for stimulating crop production may increase net GHG emission), which means that choices should be made. In this analysis E-CROP was found to be a useful tool for comparing crops and energy conversion routes and for determining agricultural input levels to optimise net energy yield and GHG emission reduction. It was also concluded that E-CROP should be improved with a soil carbon balance and feedback relations of soil organic matter and crop production.

\section{Acknowledgements}

This study was financed by the Netherlands Ministry of Economic Affairs within the framework of the "Kennisbasis10: Biobased Economy” strategic research program.

\section{References}

[1] Statistical Information. http://www.iea.org

[2] Taschner, K. (1993) Who Needs Biofuels? European Environmental Bureau, Brussels.

[3] Commission of the European Communities (2003) Directive 2003/30/EC of the European Parliament and of the Council of 17 May 2003 on the Promotion of the Use of Biofuels or Other Renewable Fuels for Transport. Brussels. 
[4] Commission of the European Communities (2009) Directive 2009/28/EC of the European Parliament and of the Council of 23 April 2009 on the Promotion of the Use of Energy from Renewable Sources. Brussels.

[5] Hammerschlag, R. (2006) Ethanol's Energy Return on Investment: A Survey of the Literature 1990-Present. Environmental Science \& Technology, 40, 1744-1750. http://dx.doi.org/10.1021/es052024h

[6] Kavanagh, E., Ed. (2006) This Weeks Letters. Science, 312, 1743-1738. http://dx.doi.org/10.1126/science.312.5781.1743a

[7] Kim, S. and Dale, B.E. (2005) Life Cycle Assessment of Various Cropping Systems Utilized for Producing Biofuels: Bioethanol and Biodiesel. Biomass and Bioenergy, 29, 426-439. http://dx.doi.org/10.1016/j.biombioe.2005.06.004

[8] Hanegraaf, M.C., Biewinga, E.E. and van der Bijl, G. (1998) Assessing the Ecological and Economic Sustainability of Energy Crops. Biomass and Bionenergy, 15, 345-355. http://dx.doi.org/10.1016/S0961-9534(98)00042-7

[9] Fischer, G. and Schrattenholzer, L. (2001) Global Bioenergy Potentials through 2050. Biomass and Bioenergy, 20, 151-159. http://dx.doi.org/10.1016/S0961-9534(00)00074-X

[10] Faaij, A.P.C. (2006) Bio-Energy in Europe: Changing Technology Choices. Energy Policy, 34, 322-342. http://dx.doi.org/10.1016/j.enpol.2004.03.026

[11] Commission of the European Communities. http://ec.europa.eu/energy/renewables/studies/land use change en.htm

[12] Commission of the European Communities. http://ec.europa.eu/energy/renewables/biofuels/land_use_change_en.htm

[13] ECS (2006) Environmental Management-Life Cycle Assessment-Principles and Framework, European Standard ISO 14040. European Committee for Standardisation, Brussels.

[14] ECS (2006) Environmental Management—Life Cycle Assessment—Requirements and Guidelines. European Standard ISO 14044. European Committee for Standardisation, Brussels.

[15] Kramer, K.J., Moll, H.C. and Nonhebel, S. (1999) Total Greenhouse Gas Emissions Related to the Dutch Crop Production System. Agriculture, Ecosystems \& Environment, 72, 9-16. http://dx.doi.org/10.1016/S0167-8809(98)00158-3

[16] van Ministerie, L.N.V. Brochure Mestbeleid 2006: Het Stelsel van Gebruiksnormen. http://www.hetlnvloket.nl

[17] Jongschaap, R.E.E. (1996) ROTASK 1.0-A Dynamic Simulation Model for Continuous Cropping Systems. Reference Manual. Report No. 70, DLO Research Institute for Agrobiology and Soil Fertility Research, Wageningen.

[18] Ten Berge, H.F.M., Withagen, J.C.M., de Ruijter, F.J., Jansen, M.J.W. and van der Meer, H.G. (2000) Nitrogen Responses in Grass and Selected Field Crops: QUADMOD Parameterisation and Extensions for STONE-Application. Report No. 24, Plant Research International, Wageningen.

[19] Schröder, J.J., Aarts, H.F.M., van Middelkoop, J.C., Schils, R.L.M., Velthof, G.L., Fraters, B. and Willems, W.J. (2007) Permissible Manure and Fertilizer Use in Dairy Farming Systems on Sandy Soils in the Netherlands to Comply with the Nitrates Directive Target. European Journal of Agronomy, 27, 102-114. http://dx.doi.org/10.1016/j.eja.2007.02.008

[20] Statistical Information. http://www.cbs.nl

[21] Dalgaard, T., Halberg, N. and Porter, J.R. (2001) A Model for Fossil Energy Use in Danish Agriculture Used to Compare Organic and Conventional Farming. Agriculture, Ecosystems \& Environment, 87, 51-65. http://dx.doi.org/10.1016/S0167-8809(00)00297-8

[22] KWIN-AGV (2006) Kwantitatieve Informatie Akkerbouw en Vollegrondsgroenteteelt 2006. PPO Publication No. 354, Praktijkonderzoek Plant \& Omgeving, Lelystad.

[23] Elsayed, M.A., Matthews, R. and Mortimer, N.D. (2003) Carbon and Energy Balances for a Range of Biofuel Options. Report B/B6/00784/REP, Energy Technology Support Unit, Harwell.

[24] Edwards, R., Larivé, J.F., Mahieu, V. and Rouveirolles, P. (2007) Well-to-Wheels Analysis of Future Automotive Fuels and Powertrains in the European Context. JRC/Concawe/Eucar Report, Ispra.

[25] van den Broek, R., van Walwijk, M., Niermeijer, P. and Tijmensen, M. (2003) Biofuels in the Dutch Market: A Fact-Finding Study. Report 2GAVE03.12, SenterNovem, Utrecht.

[26] KTBL (2009) Faustzahlen Biogas. Kuratorium für Technik in der Landwirtschaft (KTBL), Darmstadt.

[27] Vreuls, H.H.J. (2004) Nederlandse lijst van Energiedragers en Standaard $\mathrm{CO}_{2}$ Emissiefactoren. SenterNovem, Utrecht.

[28] Jenssen, T.K. and Kongshaug, G. (2004) Energy Consumption and Greenhouse Gas Emissions in Fertiliser Production. Proceedings No. 509, The International Fertiliser Society, York.

[29] IPCC 2006 IPCC Guidelines for National Greenhouse Gas Inventories, Vol. 4, Agriculture, Forestry and Other Land Use. http://www.ipcc-nggip.iges.or.jp/public/2006gl/

[30] Rathke, G.W., Christen, O. and Diepenbrock, W. (2005) Effects of Nitrogen Source and Rate on Productivity and Quality of Winter Oilseed Rape (Brassica napus L.) Grown in Different Crop Rotations. Field Crops Research, 94, 103-113. http://dx.doi.org/10.1016/j.fcr.2004.11.010 
[31] Nevens, F. and Reheul, D. (2001) Crop Rotation versus Monoculture; Yield, N Yield and Ear Fraction of Silage Maize at Different Levels of Mineral N Fertilization. NJAS—Wageningen Journal of Life Sciences, 49, 405-425.

[32] Conijn, J.G., Corré, W.J., de Ruijter, F.J. and Rutgers, B. (2012) Improvements of Environmental Performance of Oilseed Cropping Systems for Biodiesel Production. The Case of Rapeseed and Sunflower Cultivation in the European Union. Report No. 435, Plant Research International, Wageningen.

[33] Commission of the European Communities. Directive 2000/60/EC of the European Parliament and of the Council Establishing a Framework for the Community Action in the Field of Water Policy. Brussels.

[34] Dewulf, J., van Langenhove, H. and van de Velde, B. (2005) Exergy-Based Efficiency and Renewability Assessment of Biofuel Production. Environmental Science \& Technology, 39, 3878-3882. http://dx.doi.org/10.1021/es048721b

[35] Commission of the European Communities. Directive 91/676/EEC Concerning the Protection of Waters against Pollution Caused by Nitrates from Agricultural Sources. Brussels.

[36] BioGrace (2010) Harmonised Calculations of Biofuel Greenhouse Gas Emissions in Europe. http://www.biograce.net 